\title{
Cash conversion cycle and corporate performance: evidence from Romania
}

\author{
Ciprian Cristea $^{1, *}$, Maria Cristea $^{1}$
}

${ }^{1}$ Technical University of Cluj-Napoca, Faculty of Electrical Engineering, Romania

\begin{abstract}
Cash conversion cycle is considered one of the most important measures of management effectiveness, especially the cash flow and liquidity management. This study examines the relationship between cash conversion cycle and corporate profitability for the non-financial companies, from several industries, listed on the Bucharest Stock Exchange for a period of fifteen years from 2002 to 2016 . The findings from a cross sectional multiple regression analysis pointed out a negative relationship between cash conversion cycle and the performance of firms. Based on the results from this paper it has been concluded that managers can improve the profitability of their firms by decreasing the number of days in cash conversion cycle.
\end{abstract}

\section{INTRODUCTION}

Cash conversion cycle is an important metric, developed by [1], and used to assess the effectiveness of the company's overall financial health. The cash conversion cycle measures the number of days between the expenditure of the company's cash for the acquisition of raw materials to manufacture the products, and the collection of cash obtained from the sale of the finished goods [2]. Cash conversion reveals how the enterprises are performing and, at the same time, helps to dig out the areas where further improvement is demanded [3].

Cash flow management is a vital element of a company's operational strategies [4]. Cash conversion cycle is a measure of working capital efficiency. Enterprises manage working capital using three approaches: conservative, aggressive and moderate [5]. The conservative approach is where a company tends to use short-term sources only in urgent circumstances, while in other cases uses mainly long-term sources of finance for its operations. The aggressive approach utilizes higher levels of current liabilities and less longterm debt or a low level of current assets as percentage of total assets, which may lead to lower levels of liquidity [6]. In the last approach, permanent current assets are financed by long-term sources and short-term sources of finance are used to finance fluctuating current assets [5].

The cash conversion cycle has three elements: inventory conversion period, average receivables period and average payables period. Firms can improve their profitability by reducing their length of cash conversion cycle through decreasing the receivables collection period, prolonging the credit payment period or lessening the inventory selling period [7].

Many studies examined the relationship between the length of cash conversion cycle and corporate profitability. The link between the cash conversion cycle and the company profitability has been studied by [8], using a large sample of Belgian firms, and showed that for a better performance the time duration for collection of receivable should be kept short. [9] analyzed the relationship between cash conversion cycle and profitability on a sample of industrial companies and reported a negative association between the stock turnover days and the return on investment. Thus, low level of inventories was associated with high profitability. [10] found the same results on a large sample of Greek firms from food, textiles and chemical sectors. [11] conducted a study on Spanish small and medium size firms and confirmed a negative association between the profitability and the number of days accounts receivable and inventory days. Thus, companies should delay in making the payments for efficient performance. [12] investigated the relationship between working capital and profitability on a sample of 110 manufacturing companies listed on Borsa Istanbul, over the period of 2005-2014. The results pointed out that working capital negatively impacts on corporate profitability, so that firms could decrease profitability by prolonging cash conversion periods. [13] analyzed the relation between the enterprise's cash conversion cycle and its profitability using dynamic panel data analysis for a sample of Japanese firms during the period 1990-2004. The analysis is applied at the levels of the full sample and divisions of the sample by industry and by size. Results reported a negative relation between the length of the firm's cash conversion cycle and its profitability. [14] examined the relationships between cash conversion cycle and invested capital, liquidity, and performance of small U.S. manufacturing and retail firms. They found that cash conversion cycle is a significant factor in small firm capital needs, liquidity, and performance, and owners may

\footnotetext{
* Corresponding author: ciprian.cristea@emd.utcluj.ro
} 
not be proactive in managing cash conversion cycle. [15] tackled the impact of the cash conversion cycle on the profitability of a sample of Italian manufacturing firms. The results indicated that lesser the cash conversion cycle, greater the profitability.

In this paper, we examine the relationship between cash conversion cycle and profitability of non-financial companies listed on the Bucharest Stock Exchange Market for a period of fifteen years from 2002 to 2016. Multiple regression analysis is applied to explore the association between firm's cash conversion cycle and its profitability. This research has important implications because, no study, to the best of our knowledge, has examined the relationship between cash conversion cycle and corporate profitability at the level of full sample and divisions of sample by industry on the Romanian equity capital market. The rest of the paper has the following structure: in the next paragraph the methodology is described, followed by the results of this study and, the final part summarizes the conclusions.

\section{Methodology}

We selected a pooled ordinary least squares regression model to investigate the relationship between the cash conversion cycle corporate performance by adopting enterprises from different industries as samples.

The financial data were collected from the annual reports and financial statements of 330 Romanian companies listed on the Bucharest Stock Exchange Market, from 12 industries, namely wholesale/retail, construction, pharmaceuticals, manufacturing, plastics, machinery and equipment, metallurgy, chemicals, basic resources, transportation and storage, tourism, utilities, over the period 2002-2016.

The study takes return on assets as measure of profitability to represent dependent variables. The dependent variable is regressed against independent variables, namely, cash conversion cycle, firm size, debt ratio, current ratio and fixed assets ratio based on following equation:

$R O A_{i}=\alpha+\beta_{1} \cdot C C C_{i}+\beta_{2} \cdot D R_{i}+\beta_{3} \cdot C R_{i}+\beta_{4}$.

$F A_{i}+\beta_{5} \cdot S Z_{i}+\varepsilon_{i}$

where:

$\alpha$ - constant;

$\beta$ - regression coefficient;

$R O A_{i}$ - return on assets for company $i$;

$C C C_{i}$ - cash conversion cycle for company $i$;

$D R_{i}-$ debt ratio for company $i$;

$C R_{i}$ - current ratio for company $i$;

$F A_{i}$ - fixed assets ratio for company $i$;

$S Z_{i}$ - firm size for company $i$;

$\varepsilon-$ error term.

Return on assets indicates how profitable a firm is relative to its assets and is measured as the ratio of net income to total assets. Cash Conversion Cycle is calculated as the number of days of inventory plus the number of days of receivables less the number of days of payables. The formula for computing cash conversion cycle is as follows:

$C C C_{i}=D I O_{i}+D S O_{i}-D P O_{i}$

where:

$D I O_{i}$ - days inventory outstanding for company $i$; $D S O_{i}$ - days sales outstanding for company $i$; $D P O_{i}$ - days payable outstanding for company $i$.

The days inventory outstanding ratio is calculated as follows:

$D I O_{i}=\frac{I n v_{i} \cdot 365}{\operatorname{COGS}_{i}}$

where:

$\operatorname{In} v_{i}$ - inventory for company $i$;

$C O G S_{i}-$ cost of goods sold for company $i$.

The days sales outstanding ratio is determined as follows:

$\operatorname{DSO}_{i}=\frac{A R_{i} \cdot 365}{\operatorname{Sal}_{i}}$

where:

$A R_{i}$ - account receivable for company $i$;

$\mathrm{Sal}_{i}$ - sales for company $i$.

The days payable outstanding ratio is computed as follows:

$D P O_{i}=\frac{A P_{i} \cdot 365}{\operatorname{COGS}_{i}}$

where:

$A P_{i}$ - account payable for company $i$.

Debt ratio is defined as the ratio of total debt to total assets. Current ratio is determined as the ratio of current assets to current liabilities. Fixed assets ratio is obtained as the ratio of fixed assets to total assets. Size of the firm is measured by using the natural logarithm of total assets.

\section{Results}

Table 1 presents the descriptive statistics for the variables used in this study. This table shows the average of the variables from the full sample and industries between the years 2002 and 2016. Manufacturing is the industry with the highest firm observations, accounting for $33.64 \%$ of the total sample size, while, pharmaceutics, chemicals and utilities exhibit the lowest firm observations, accounting for $1.52 \%$. The average cash conversion cycle for Romanian firms was 182.64 days, which is considerably higher that of Italian manufacturing firms (79.34 days) [15] and US manufacturing companies (54.18 days) [14], but lower than the average cash conversion cycle of listed companies on the Athens Stock Exchange (189 days) [16]. We could see that the lowest average cash conversion cycle is found in utilities industry, with an average of 46.89 day, and the highest average value of the cash conversion cycle is found in the machinery and equipment industry, with an average of 251.77 days. 
Table 1. Descriptive statistics (mean values of variables).

\begin{tabular}{|c|c|c|c|c|c|c|c|c|}
\hline Industry & $\begin{array}{c}\text { No. of } \\
\text { companies }\end{array}$ & Percentage & ROA & CCC & CR & SZ & FA & DR \\
\hline Wholesale/retail & 62 & $18.79 \%$ & 0.050423 & 195.8492 & 4.967184 & 16.19128 & 0.62271 & 0.270808 \\
\hline Construction & 43 & $13.03 \%$ & 0.013462 & 234.6195 & 3.052749 & 16.70483 & 0.587786 & 0.372402 \\
\hline Pharmaceuticals & 5 & $1.52 \%$ & 0.054837 & 166.135 & 2.780126 & 18.37409 & 0.363298 & 0.367251 \\
\hline Plastics & 6 & $1.82 \%$ & 0.054777 & 67.43166 & 1.163833 & 16.99983 & 0.636039 & 0.397582 \\
\hline $\begin{array}{c}\text { Machinery and } \\
\text { equipment }\end{array}$ & 24 & $7.27 \%$ & -0.0004 & 251.7786 & 2.966687 & 17.15166 & 0.55625 & 0.408223 \\
\hline Metallurgy & 9 & $2.73 \%$ & -0.0326 & 105.4802 & 1.262787 & 19.32892 & 0.566317 & 0.710661 \\
\hline Manufacturing & 111 & $33.64 \%$ & 0.016524 & 173.1453 & 5.104269 & 16.88651 & 0.534869 & 0.340303 \\
\hline Chemicals & 5 & $1.52 \%$ & 0.027331 & 111.3905 & 1.662096 & 18.47774 & 0.668075 & 0.42066 \\
\hline Basic resources & 15 & $4.55 \%$ & 0.059306 & 117.5791 & 3.514736 & 18.32981 & 0.643547 & 0.37898 \\
\hline $\begin{array}{c}\text { Transportation } \\
\text { and storage }\end{array}$ & 14 & $4.24 \%$ & 0.027475 & 112.573 & 4.000161 & 16.77677 & 0.675511 & 0.221699 \\
\hline Tourism & 31 & $9.39 \%$ & -0.00725 & 196.7439 & 9.656167 & 16.30307 & 0.795546 & 0.187083 \\
\hline Utilities & 5 & $1.52 \%$ & 0.047511 & 46.8978 & 4.277155 & 21.7455 & 0.697744 & 0.24413 \\
\hline Full sample & 330 & $100 \%$ & 0.022272 & 182.647 & 4.713359 & 16.92038 & 0.598068 & 0.328367 \\
\hline
\end{tabular}

It may be concluded that on an average, basic resources companies are facing the highest profitability (0.059), while metallurgy companies are facing the lowest profitability (-0.032), as represented by return on assets.
Figure 1 shows the evolution of cash conversion cycle for the Romanian companies between the years 2002 and 2016.

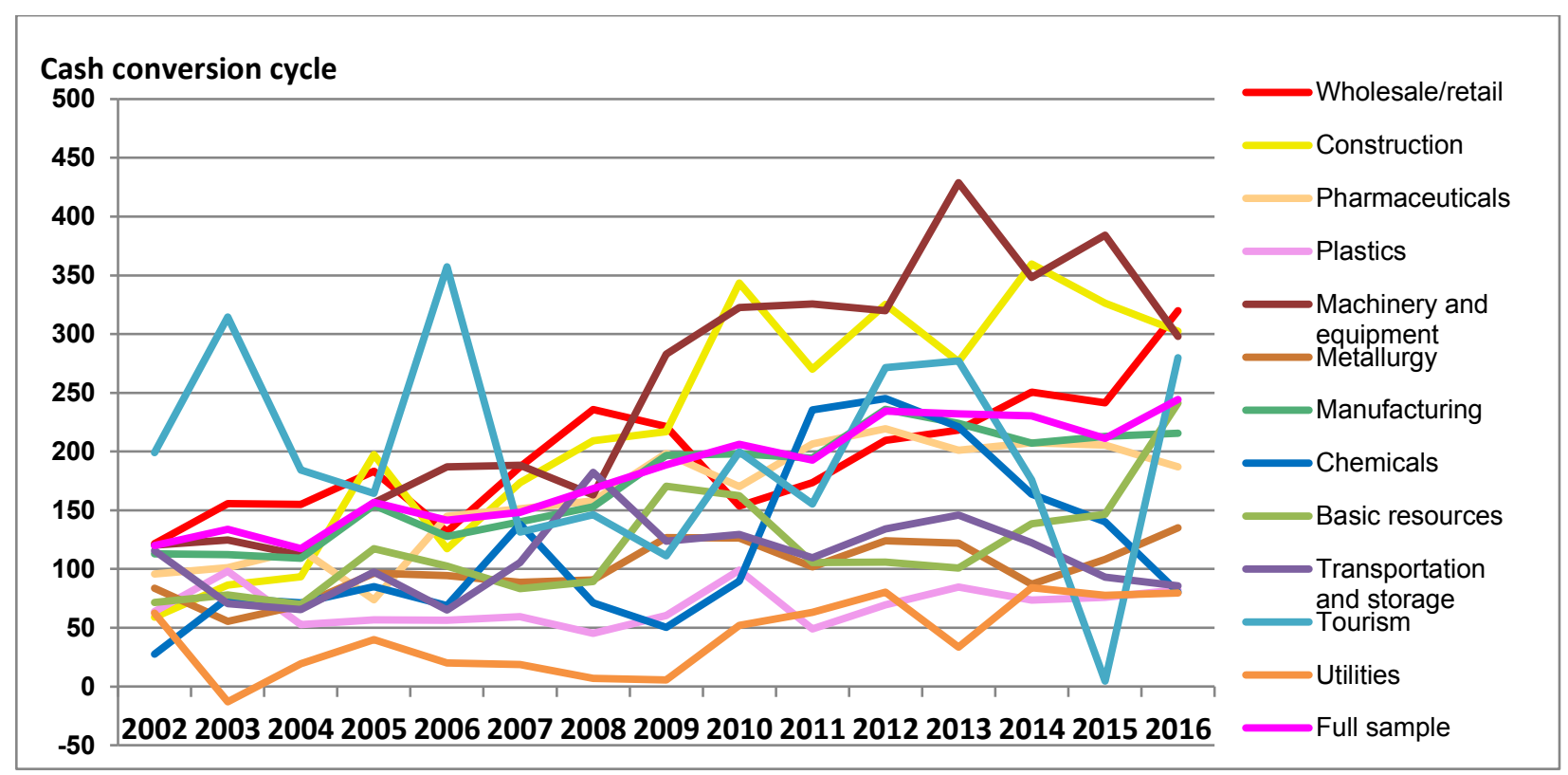

Fig.1 The evolution of cash conversion cycle for the Romanian companies from 2002 to 2016

It can be noticed an upward trend in cash conversion cycle values for the full sample of firms and at the same time utilities companies exhibit the lowest value in most years. Tourism companies are the most volatile in terms of cash conversion cycle values during the analyzed period.

The estimated coefficients based on equation (1) are presented in table 2 . The results indicate that the length of the cash conversion cycle had a negative impact on the corporate performance, measured by return on assets for the full sample and for all the industries, except for metallurgy and utilities companies. This indicates that larger the cash conversion cycle is, smaller would be the firm profitability. These results are consistent with the results of the existing cash conversion cycle literature such as $[8,12,13,14]$.

Table 2. Regression results.

* Corresponding author: ciprian.cristea@emd.utcluj.ro 


\begin{tabular}{|c|c|c|c|c|c|c|c|c|}
\hline Industry & Constant & $\mathrm{CCC}$ & CR & SZ & FA & DR & $\begin{array}{c}\text { Adjusted } \\
\text { R-squared }\end{array}$ & F-statistic \\
\hline $\begin{array}{c}\text { Wholesale/retail } \\
\text { (Prob.) }\end{array}$ & $\begin{array}{c}0.207931 \\
(0)\end{array}$ & $\begin{array}{c}-0.00031 \\
(0) \\
\end{array}$ & $\begin{array}{c}0.000333 \\
(0.2618) \\
\end{array}$ & $\begin{array}{c}-0.006947 \\
(0)\end{array}$ & $\begin{array}{c}-0.066744 \\
(0)\end{array}$ & $\begin{array}{l}-0.01289 \\
(0.0087) \\
\end{array}$ & 0.209318 & 46.95729 \\
\hline $\begin{array}{l}\text { Construction } \\
\text { (Prob.) }\end{array}$ & $\begin{array}{c}0.134451 \\
(0)\end{array}$ & $\begin{array}{c}-0.00037 \\
(0)\end{array}$ & $\begin{array}{c}-0.000453 \\
(0.6583)\end{array}$ & $\begin{array}{l}7.99^{\mathrm{E}}-05 \\
(0.9583)\end{array}$ & $\begin{array}{c}-0.11739 \\
(0)\end{array}$ & $\begin{array}{c}-0.094129 \\
(0)\end{array}$ & 0.204751 & 31.02083 \\
\hline $\begin{array}{c}\text { Pharmaceuticals } \\
\text { (Prob.) }\end{array}$ & $\begin{array}{c}-0.087492 \\
(0.2303)\end{array}$ & $\begin{array}{l}-0.00082 \\
(0.1859) \\
\end{array}$ & $\begin{array}{c}0.011081 \\
(0.1108) \\
\end{array}$ & $\begin{array}{l}0.00717 \\
(0.0481) \\
\end{array}$ & $\begin{array}{c}0.025068 \\
(0.6703)\end{array}$ & $\begin{array}{c}-0.041546 \\
(0.172)\end{array}$ & 0.225839 & 5.084099 \\
\hline $\begin{array}{c}\text { Plastics } \\
\text { (Prob.) }\end{array}$ & $\begin{array}{c}-0.074353 \\
(0.6255) \\
\end{array}$ & $\begin{array}{c}-0.00336 \\
(0.227) \\
\end{array}$ & $\begin{array}{c}0.038412 \\
(0.2343) \\
\end{array}$ & $\begin{array}{c}-0.001904 \\
(0.6441) \\
\end{array}$ & $\begin{array}{l}0.10558 \\
(0.3144) \\
\end{array}$ & $\begin{array}{c}0.159371 \\
(0.1332) \\
\end{array}$ & 0.062080 & 1.93988 \\
\hline $\begin{array}{l}\text { Machinery and } \\
\text { equipment } \\
\text { (Prob.) }\end{array}$ & $\begin{array}{l}0.001495 \\
(0.9698)\end{array}$ & $\begin{array}{c}-0.0073 \\
(0)\end{array}$ & $\begin{array}{c}-0.000836 \\
(0.1532)\end{array}$ & $\begin{array}{l}0.010107 \\
(0)\end{array}$ & $\begin{array}{c}-0.152555 \\
(0)\end{array}$ & $\begin{array}{c}-0.157801 \\
(0)\end{array}$ & 0.266502 & 24.76174 \\
\hline $\begin{array}{c}\text { Metallurgy } \\
\text { (Prob.) }\end{array}$ & $\begin{array}{c}-0.182421 \\
(0.3669) \\
\end{array}$ & $\begin{array}{l}0.00076 \\
(0.7549) \\
\end{array}$ & $\begin{array}{l}0.00321 \\
(0.6081) \\
\end{array}$ & $\begin{array}{c}0.008165 \\
(0.286) \\
\end{array}$ & $\begin{array}{c}0.151732 \\
(0.1906) \\
\end{array}$ & $\begin{array}{c}-0.121098 \\
(0.0046) \\
\end{array}$ & 0.118174 & 3.653409 \\
\hline $\begin{array}{c}\text { Manufacturing } \\
\text { (Prob.) }\end{array}$ & $\begin{array}{r}0.051867 \\
(0.0019) \\
\end{array}$ & $\begin{array}{c}-0.00062 \\
(0) \\
\end{array}$ & $\begin{array}{c}-0.000187 \\
(0.0099) \\
\end{array}$ & $\begin{array}{c}0.005749 \\
(0) \\
\end{array}$ & $\begin{array}{c}-0.141411 \\
(0) \\
\end{array}$ & $\begin{array}{c}-0.119386 \\
(0) \\
\end{array}$ & 0.224692 & 91.88463 \\
\hline $\begin{array}{c}\text { Chemicals } \\
\text { (Prob.) }\end{array}$ & $\begin{array}{c}-0.229106 \\
(0.2273)\end{array}$ & $\begin{array}{l}-0.0019 \\
(0.048) \\
\end{array}$ & $\begin{array}{c}0.017922 \\
(0.2183) \\
\end{array}$ & $\begin{array}{c}0.021742 \\
(0.0833) \\
\end{array}$ & $\begin{array}{c}-0.232924 \\
(0.0524)\end{array}$ & $\begin{array}{c}-0.100966 \\
(0.6096) \\
\end{array}$ & 0.085768 & 2.163299 \\
\hline $\begin{array}{c}\text { Basic resources } \\
\text { (Prob.) }\end{array}$ & $\begin{array}{l}0.21352 \\
(0.0002)\end{array}$ & $\begin{array}{l}-0.00097 \\
(0.0445)\end{array}$ & $\begin{array}{c}-0.001306 \\
(0)\end{array}$ & $\begin{array}{c}-0.001684 \\
(0.3086)\end{array}$ & $\begin{array}{r}-0.09007 \\
(0.0009)\end{array}$ & $\begin{array}{c}-0.147457 \\
(0.0004)\end{array}$ & 0.176609 & 9.450929 \\
\hline $\begin{array}{l}\text { Transportation } \\
\text { and storage } \\
\text { (Prob.) }\end{array}$ & $\begin{array}{c}-0.117851 \\
(0.0722)\end{array}$ & $\begin{array}{c}-0.00054 \\
(0.1219)\end{array}$ & $\begin{array}{c}-0.000975 \\
(0.4917)\end{array}$ & $\begin{array}{c}0.017414 \\
(0)\end{array}$ & $\begin{array}{c}-0.166038 \\
(0)\end{array}$ & $\begin{array}{c}-0.126479 \\
(0.0024)\end{array}$ & 0.369132 & 22.06427 \\
\hline $\begin{array}{c}\text { Tourism } \\
\text { (Prob.) }\end{array}$ & $\begin{array}{c}0.056362 \\
(0.2238)\end{array}$ & $\begin{array}{r}-0.00187 \\
(0.0897) \\
\end{array}$ & $\begin{array}{c}-0.00026 \\
(0.0024)\end{array}$ & $\begin{array}{c}0.006603 \\
(0.0071)\end{array}$ & $\begin{array}{c}-0.141226 \\
(0)\end{array}$ & $\begin{array}{c}-0.210717 \\
(0)\end{array}$ & 0.23233 & 25.81674 \\
\hline $\begin{array}{l}\text { Utilities } \\
\text { (Prob.) }\end{array}$ & $\begin{array}{c}0.132428 \\
(0.05)\end{array}$ & $\begin{array}{l}0.00084 \\
(0.0343)\end{array}$ & $\begin{array}{c}-0.002831 \\
(0.0158)\end{array}$ & $\begin{array}{c}0.002497 \\
(0.4753)\end{array}$ & $\begin{array}{r}-0.15672 \\
(0.0001)\end{array}$ & $\begin{array}{c}-0.10336 \\
(0.0001)\end{array}$ & 0.344105 & 7.190672 \\
\hline $\begin{array}{c}\text { Full sample } \\
\text { (Prob.) }\end{array}$ & $\begin{array}{c}0.074456 \\
(0)\end{array}$ & $\begin{array}{c}-0.00035 \\
(0)\end{array}$ & $\begin{array}{c}-0.000183 \\
(0.0006)\end{array}$ & $\begin{array}{c}0.002962 \\
(0)\end{array}$ & $\begin{array}{c}-0.108511 \\
(0)\end{array}$ & $\begin{array}{c}-0.093308 \\
(0)\end{array}$ & 0.16975 & 185.2158 \\
\hline
\end{tabular}

Results of the debt ratio show that the debt level of a company has a significant negative effect on the company's performance for the full sample and for all the industries of the study except plastics companies, where the findings are not statistically significant. The results reported show a negative relationship between the ability of a company to cover its short-term liabilities with its current assets and profitability for the full sample and for all the industries of the paper except wholesale/retail pharmaceuticals, plastics, metallurgies and chemical companies, where the findings are not statistically significant.

\section{Conclusions}

The cash conversion cycle is an important performance metric for analyzing how well a company is managing its working capital. In this paper, a negative relationship was found between the cash conversion cycle and corporate performance for the full sample of companies, and for all industries except of metallurgy and utilities. The results also show that the debt ratio and current ratio have a negative effect on the enterprise's performance for the full sample. These findings recommend that managers of the Romanian companies can enhance the profitability of their firms by lessening the cash conversion cycle.

\section{References}

1. V. D. Richards and E. J. Laughlin, Financ. Manage., 9(1), 32-38 (1980)

2. C. R. Sathyamoorthi, L. B. Wally-Dima, J. Manage. Res., 7(5), 7-24 (2008)
3. P. D. Hutchison, M. T. Farris II, S. B. Anders, CPA J., 77(8), 42-47 (2007)

4. J. R. Kroes, and A. S. Manikas, Int. J. Prod. Econ., 148, 37-50 (2014)

5. Ukaegbu B., Res. Int. Bus. Financ., 31, 1-16 (2014)

6. J. C. Van Horne, J. M. Wachowicz, Fundamental of Financial Management (12 ${ }^{\text {th }}$ ed., Prentice Hall, 2004)

7. R. Anser and Q. A. Malik, JBM, 8(2), 83-87 (2013)

8. M. Deloof, J. Bus. Finan. Account., 30, 573-587 (2003)

9. K. Padachi, Int. Rev Bus. Res. Pap., 2(2), 45-58 (2006)

10. D. P. Koumanakos, Int. J. Prod. Perform. Manag., 57(5), 335-369 (2008)

11. P. J. G. Teruel and P. M. Solano, Int. J. Manag. Financ., 3(2), 164-177 (2007)

12. M. Öner, Res. J. Polit. Econ. Manag., 4, 63-79 (2016)

13. H. Nobanee, M. Abdullatif, M. AlHajjar, Asian Rev. Account., 19(2), 147-156 (2011)

14. J.J.Ebben,A.C.Johnson,J.SmallBusEntrep,24(3),380-396(2011)

15. M. Muscettola, Int. J. Bus. Manag., 9, 25-35 (2014)

16. I. Lazaridis, D. Tryfonidis, J. Financ. Manag. Anal., 19 (1), 26-35 (2006) 